\title{
Counterterrorism and Immigration in Hungary
}

\author{
Phoenix Berman \\ College of Liberal Arts and Sciences
}

Faculty Mentor: Zachary Selden, Department of Political Science

\begin{abstract}
The European migration crisis beginning in 2014 served as a turning point in Hungarian politics where immigration issues effectively altered the nation's security environment. The migratory routes as a pathway for illegal border crossings positioned Hungary on the frontline as a transit country for migrants seeking asylum in Western Europe. A critical analysis of Prime Minister Viktor Orbán's rhetoric and Hungary's behavior in the realm of immigration and counterterrorism (CT) policy during and after the immigration crisis is relevant in understanding the state's security environment. Anti-immigrant sentiments reflected in the population and Orbán's rhetoric aims to tie refugee migration to terrorist acitvity. Migrants were targeted as a risk to the traditional European identity and survival of the state with a specific emphasis on Muslim migration from the Middle East and North Africa. This study seeks to understand Hungary's regional and global security role, and how CT activity is used by the government to legitimize government actions, particularly on immigration via securitization theory from the Copenhagen School. Hungary has heightened its role on the international stage through transnational CT cooperation and capitalized on anti-immigrant sentiments through speech acts to further exercise its influence in border control and the international fight against global terrorism. By examining a total of 36 speeches presented by Orbán from 2015 to 2020, the study is able to examine how immigration issues were securitized to develop pathways for extraordinary actions and authoritarian reforms performed by securitizing actors.

Keywords: immigration, terrorism, Hungary, European Union, security
\end{abstract}

\section{Introduction}

Cvrtila, Slijepčević, and Levak note in their study titled "Migration, The Perception Of Security Risks And Media Interpretation Frameworks In Croatia And Hungary” (2019), that through securitization theory, issues facing a state are posed as a "question of security" to allow a populist government to take full control when resolving security risks. In the case of Hungary, anti-immigrant sentiments reflected in the population are used by securitizing actors to accomplish counterterrorism (CT) and immigration positions in support of Prime Minister Viktor Orbán. Through the process of securitization, migrants are targeted as a risk to the traditional identity and state security with a specific emphasis on Muslim migration from the Middle East 
and North Africa. This study seeks to understand Hungary's regional and global security role and how counterterrorism activity is used by the government to legitimize government actions, particularly on immigration. Through Hungary's membership in the European Union (EU) and the Visegrad Group (V4), Hungary leverages CT policy and immigration as a means to heighten its position through regional securitization. Hungary's response to the European migration crisis since 2015 has enabled it to transform domestic issues of immigration to high politics and engage in transnational CT operations - earning Hungary the region's only United Nations (UN) Office of Counter-Terrorism. These developments are particularly notable considering Hungary's lack of a substantial immigrant population or terrorist attacks associated with the migration crisis. A critical analysis of Orbán’s rhetoric and Hungary’s behavior in the realm of immigration and CT policy is relevant in understanding the state's security environment through the lens of securitization theory.

\section{The European Migration Crisis}

The European migration crisis beginning in 2014 and ending in 2019 served as a turning point in Hungarian politics where immigration issues transcended from domestic to high politics by securitizing actors. As transnational migration exponentially increased on the European front, by 2015 the EU experienced the arrival of more than one million "irregular migrants" ("Facilitation of Illegal", n.d.). The migratory routes as a pathway for illegal border crossings contextualize the frontline of Hungary's immigration issue. Two migratory routes afflicting Hungary's borders include the Western Balkan Route and the Eastern Borders Route (Frontex). On the Western Balkan front, Hungary assessed that religious extremism could be found in Bosnia and Herzegovina, Albania, Kosovo, and North Macedonia where formal and informal groups had contact with jihadist ideologies (“Trend Report”, 2020, p. 52). Terrorist groups including al-Qaeda and Islamic State of Iraq and the Levant (ISIS) targeted Western Balkan Muslim populations (“Trend Report”, 2020, p. 52). Terrorist activities and crime concerning illegal immigration bolstered Orban's anti-immigration rhetoric and policies.

\section{Security Issues in the Irregular Migration Flows}

During the European migration crisis, Europe faced the introduction of Islamist extremists who entered Europe's external borders. At least 104 Islamist extremists entered the EU's external borders via irregular migration flows from 2014 to 2018 (Bensman, 2019). In some cases, terrorists were deposited in irregular migration flows by organized terrorist groups. 
A total of 40 out of 65 terrorists that were involved in completed or thwarted attacks in Europe impersonated refugees (Bensman, 2019). Of these 40 terrorists, 27 composed a cell for ISIS who were primarily deployed into the Western Balkan route travelling through Hungary to successfully conduct some of the highest-casualty attacks in France and Belgium (Bensman, 2019). While jihadist attacks were heavily concentrated in Western Europe, it is important to note that active Hungarian CT policy played a role in combatting terrorism during the migration crisis.

Terrorists who utilized irregular migration flows found opportunity through the Western Balkan route using Hungary as a transit country before reaching Western Europe. Hungary's Counter-Terrorism Center (TEK) successfully detained jihadist militants in Hungary planning or initiating attacks. The TEK intercepted jihadist militants who were planning a series of bombings including an attack on Budapest ("Budapesten is terveztek", 2015). Terrorists who traveled to Western Europe via Hungary to carry out the bombings or recruit people were apprehended by the TEK and European police ("Budapesten is terveztek", 2015). The year prior, the TEK also arrested several people in Hungary that were suspected to join terrorist groups including a Danish girl who wanted to become an ISIS fighter and two teen boys that were preparing to depart for training in Syria ("Budapesten is terveztek", 2015). Terrorists who utilized the Western Balkan migratory route were also found to have reached Hungary prior to conducted or planned attacks in Western Europe - as well as applying for asylum in Hungary (Bensman, 2019). While the migration crisis was an avenue for terrorism, terrorists in the irregular migration flows only represented a fraction of the migrants seeking refuge in Europe. Given the relatively small number of actual threats posed to Hungarian security, therefore, it is difficult to understand how this issue became a dominant position in Hungarian politics. Viewing this through the lens of securitization could provide an explanation.

\section{Securitization Theory}

The concept of securitization theory originates from the Copenhagen School and is intended to analyze threats to states as being socially constructed (Romaniuk, 2018). Therefore, security discourse is characterized by "dramatizing an issue" to the extent that it becomes the state's top security priority (Wæver, 1996, p. 106). An actor transforms issues of domestic level politics into matters of high politics that impact the state at the national level (Romaniuk, 2018). The three phases of the securitization process includes the creation of an existential threat, executing 
extraordinary actions, and the reception of a speech act by one or more audiences (Romaniuk, 2018). Securitization is self-referential for Hungary where an existential threat (immigration) is created before the referent object (the nation), extraordinary actions are taken to protect the referent object (national identity), and then a speech act to an audience is followed where "something is done" (Wæver, 1996, p. 106).

In Hungary, through the process of securitization migrants are targeted as a risk to the traditional identity and survival of the state. National identity is the mode by which the state and subsequently Orbán - is aware that it will gain support for bringing migrants and immigration into the realm of high politics. This securitization strategy capitalizes on the highly nationalistic tendencies of the Hungarian population. Immigration is securitized as a means to protect Hungarian national identity by triggering the Hungarian opposition towards migrants and extending extraordinary actions into immigration policies (Cvrtila, Slijepčević \& Tomislav Levak 12). Extraordinary measures include authoritarian reforms in a time of crisis or political uncertainty (Cvrtila, Slijepčević \& Tomislav Levak, 2019, p. 13). Developing a security policy that seeks to target foreigners and cracks down on immigration contributes to the development of xenophobic ideologies at the public and governmental level.

\section{Speech Acts and Counterterrorism Policy}

The study analyzed through the lens of securitization theory 36 speeches given by Orbán as seen in Figure 1. These speech acts were administered publicly by Orbán from 2015 to 2020. Extractions from each speech were made by focusing on phrases relating to immigration and terrorism. A word cloud was created where words were based on frequency of appearance and limited to a display of 100 phrases. Over this five-year span during the height and plateau of the European migration crisis, Orbán emphasized phrases including “Europe”, “border”, “crime”, "threat of terrorism", "danger", "security", "culture", and the "Muslim world". Orbán claimed that migrants from North Africa and the Middle East were from "parallel societies" and a threat to European values and culture. In a speech at the V4 Conference in 2018, Orbán stated that the creation of immigrant societies leads to, “...parallel societies, terrorism, the deterioration of public security...” (“The Future of Europe”, 2018). Furthermore, Orbán stated that migrants from North Africa and the Middle East "imported" issues like crime, terrorism, homophobia, and anti-Semitism in European areas with high numbers of immigrants ("Bild címü német napilapnak", 2016). By contextualizing place of origin and commenting on the "Muslim world", 
Orbán conflated migrants who follow Islam as Europe’s top security issue. Orbán explicitly defined that Hungary does not want a "significant Muslim community" and that Europe should be aware of "the Islamization of Europe" ("14 $14^{\text {th }}$ Kötsze", 2015). For Orbán, the presence and integration of migrants only leads to a society rampant with crime and an overall decay of the socalled European and Hungarian way of life.

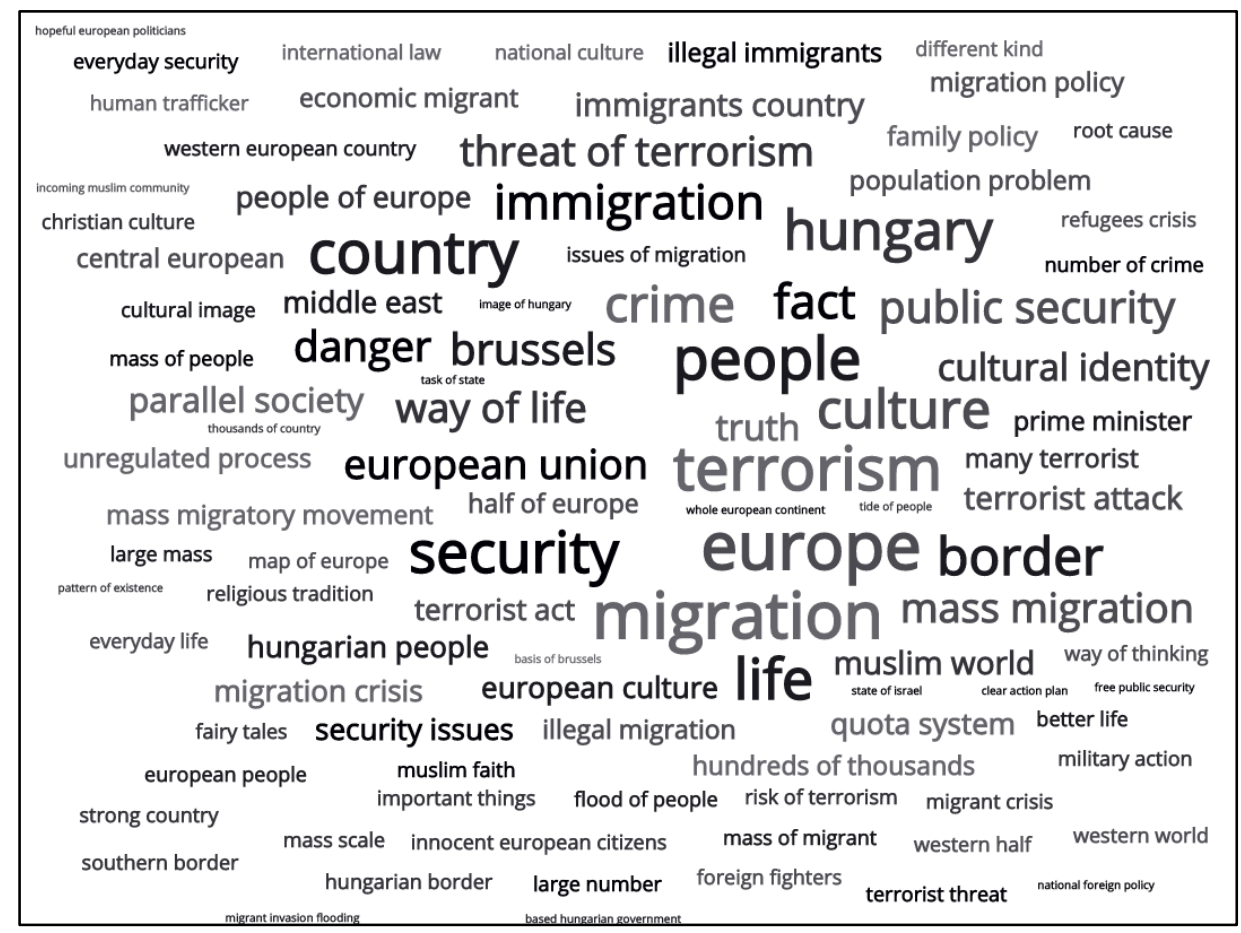

Figure 1. Word Cloud Extractions of 36 Official Speeches by Orbán from 2015-2020

Orbán defined the mass migratory movement as a fabricated crisis composed of economic migrants, refugees, and foreign fighters coming in "unregulated" and "unchecked" masses at Europe's borders. Furthermore, he noted that the migration crisis had the ability to destabilize Europe as a whole (“EPP”, 2015). Orbán found rhetorical weight by emphasizing that through irregular migration it is not clear who the true refugees are. In a 2015 interview with Politico, Orbán stated, “... [the] factual point is that all the terrorists are basically migrants” (Kaminski, 2015). Through this speech act Orbán declared migrants to be terrorists and capitalized on security threats posed by irregular migration to further his anti-immigrant agenda. Furthermore, Orbán stated that the EU level quota system should be "attacked" as it was "spreading terrorism in Europe" ("180 Perc", 2015). Orbán developed a victimhood narrative that Hungary worked to 
defend Europe while suffering a lack of support from Brussels. From Orbán’s perspective, the "European left" were seeking a "politically constructed world society" without nations, borders, or religious traditions (“EPP”, 2015). The critical point for Orbán was to stress the importance of the national competency over borders which further supports and justifies the extraordinary action of creating the border wall with Serbia and Croatia. Orbán believed that the "European left" aimed to attack "core" European values including family and the nation ("EPP”, 2015). Orbán further securitized the issue of immigration by claiming that the global "elites" and European left were planning to take power by exacerbating migration, creating "mixed ethnicity", "open societies”, and destroying national sovereignty ("Magyar Nemzet”, 2020).

\section{CT Policy}

In 2010 Hungary formally created its Counter-Terrorism Center (TEK) as a response to increasing terror attacks in Western Europe (“Working Together”, 2019). Hungary's national security strategy published in 2012 outlined that with the impact of globalization and that "EuroAtlantic" integration would lead to a future where the country would become increasingly vulnerable to associated threats. ("National Security", 2012) In the security strategy, it is stated that due to a globalized world, security stretches beyond the political borders of Hungary especially with the risk of terrorism. Hungary outlined that the security of its Eastern and Southern neighborhood is in the interest of the country's security as well as Europe's which can be achieved through bilateral relations and regional cooperation to enhance stability (natl security). A point on the respect for cultures is outlined as a security policy for Hungary where preservation of diversity and protection of common values of communities internally and externally as reinforced by the Treaty of Lisbon. ("National Security", 2012)

In the 2012 national security strategy, terrorism is viewed as a significant threat that challenges the country's alliances and core values ("National Security", 2012). While the strategy outlined that the comprehensive threat of terrorism was low in the nation, it emphasized that the country should be prepared for terrorist attacks abroad that could have reciprocal effects on its security and economic environment ("National Security", 2012). Furthermore, the strategy states that an effective response includes an entire investment of the Hungarian government, capacity and institution-building measures, and synchronization of authorities. In a 2017 speech, Orbán noted that the threat of terrorism can "never be reduced to zero" but that the risk in Hungary remained "very low" ("Chamber of Commerce", 2017). However, that same year the 
Hungarian government continued to increase funding to the TEK where the Ministry of the Interior's budget exceeded its limit by HUF 3.7 billion amounting to HUF 90 billion in CT funds (Koncz, 2017). Considering the minimal threat of domestic terror attacks by migrants in Hungary, the government successfully securitized the threat of both immigration and terrorism to identity as a tool to enhance their CT positions.

In 2019 the UN and Hungary's Ministry of Foreign Affairs and Trade announced that Budapest would host the only regional headquarters for the UN Office of Counte-Terrorism (“Budapest to Host”, 2019). This monumental move for Hungary’s CT efforts and global recognition builds off of several years of global diplomacy and security initiatives. Hungary, as an independent actor as well a member of the V4, developed strategic alliances with Western Balkan, North African, and Middle Eastern governments in the effort to combat terrorism and create cooperative defense and police operations ("Hungary-Tunisia", 2019). The overarching theme from all Hungarian CT initiatives is that immigration is directly linked to jihadist terrorism. Therefore, it is the Hungarian position to enact severe controls on immigration to prevent terrorism in Europe as a means to protect its national security and identity. The Hungarian government has publicly outlined their goals to maintain the state as an ethnically homogenous and Christian nation as a means to protect Hungarian heritage which is a testament to the success of Orbán’s securitization efforts ("Chamber of Commerce”, 2017).

\section{Extraordinary Actions}

The effect of Orbán's speech acts can be seen in the extraordinary actions taken by the govenrment to legitimize policy positions on immigration - whether legal or not. In 2015 the "state of crisis" was introduced into Hungarian law and extended from border counties to include the entire Hungarian territory in 2016 ("State of Crisis", 2019). Through this "crisis situation caused by migration" two transit zones were created where only applications for international protection could be submitted with minor exceptions ("Broke Asylum Law"; 2020, "State of Crisis", 2019). This state of crisis increased powers of the law enforcement who were able to "take all effective measures" to push back asylum seekers across the border fence without a formal legal procedure to challenge police authority ("State of Crisis", 2019). This action was declared illegal by the European Court of Justice in 2020 ("Broke Asylum Law", 2020). The state of crisis suspended measures of the Hungarian Asylum Act which limited the rights of asylum seekers creating deplorable conditions and lack of access to areas like the labor market 
and travel allowances ("Broke Asylum Law", 2020). Orbán furthered the government's antiimmigrant agenda by criminalizing assistance to unauthorized migrants via the "Stop Soros Law" which effectively introduced a new crime of "facilitating immigration" as a threat to national security (“Stop Soros”, 2018).

During the height of the European migration crisis, Hungary and other members of the V4 opposed the refugee quotas established by the EU ("EU to Sue Poland", 2017). The refusal of EU-level quotas in addition to the construction of a barbed-wire fence along the border with Serbia and Croatia can be seen as an example of political opportunism in taking extraordinary actions by securitizing actors. The European Agenda on Migration adopted by the European Commission in 2016 required that of the 160,000 migrants requiring resettlement Hungary would have had to accept 1,294 migrants ("State of Play", 2016). Hungary was in direct violation of the Common European Asylum System by taking the extraordinary action to refuse asylum applications ("Response to the Migrant Crisis", 2017). Additionally, these actions exploited and were justified by anti-immigrant sentiments present in the Hungarian population. According to a 2015 Eurobarometer study, Hungary had statistically lower acceptance of the EU common migration policy and a higher proportion of respondents who supported increased measures to combat immigration compared to the EU average (Simonovits \& Bernát, 2016). In a 2017 Eurobarometer study, $51 \%$ of Hungarian respondents felt personally uncomfortable with all or at least one social relationship with an immigrant, while $41 \%$ did not see the necessity in fostering the long-term integration of immigrants in Hungarian society ("Eurobarometer 469”, 2018). Considering the climate of Hungarian public opinion at the time, Orbán capitalized on domestic sentiments as the platform to execute extraordinary actions through securitization.

\section{Conclusion}

Through the Copenhagen School's theory of securitization, it can be seen that Hungarian security actors successfully capitalized on anti-immigrant sentiments through various forms of speech acts. By defining the existential threat of immigration and terrorism before the nation, Hungary has been able to take extraordinary actions to protect national identity and security. At the expense of irregular migrants from the Middle East and North Africa, Hungary developed a security narrative that married immigration, terrorism, and jihadist extremism. Through its alliance in the V4, Hungary has extended its perceived security threats to its surrounding neighborhood thus developing a regional security complex within the EU. Through Orbán’s anti- 
immigrant speech acts, Hungary continued its national security aims outlined in its 2012 national security strategy. This use of Orbán's securitization strategy in taking extraordinary actions and continued speech acts into 2020 exhibits the maturation of CT policy as a fundamental pillar of modern Hungarian society even after the conclusion of the migration crisis. Through the securitization of immigration and terrorism, Hungary has heightened its role on the international stage through transnational CT cooperation and hosting the region's only UN office for CounterTerrorism. The UN and other international actors have legitimized Hungary's policy positions concerning immigration and CT which allows the state to further exercise its influence in border control and the international fight against terrorism.

\section{References}

Bensman, T. (2019, November 6). Data: Terrorist Migration Over European Borders (2014-2018). Retrieved March 30, 2021, from https://cis.org/Report/Terrorist-Migration-Over-EuropeanBorders

Bocskor, Á. (2018). Anti-Immigration Discourses in Hungary during the 'Crisis' Year: The Orbán Government's 'National Consultation' Campaign of 2015. Sociology, 52(3), 551-568. doi:10.1177/0038038518762081

Budapest to Host UN Regional Counter-Terrorist Support Office. (2019, November 07). Retrieved March 30, 2021, from https://hungarytoday.hu/budapest-united-nations-counter-terrorism-office/

Cvrtila, V., Slijepčević, M., \& Levak, T. (2019). Migration, The Perception Of Security Risks And Media Interpretation Frameworks In Croatia And Hungary. Studia Polensia, 8(1), 7-30. doi:10.32728/studpol/2019.08.01.01

Együtt újra sikerülni fog. (2020, September 21). Retrieved March 30, 2021, from https://miniszterelnok.hu/egyutt-ujra-sikerulni-fog-2/

European Union, European Commission. (2018, April). Special Eurobarometer 469 Integration of Immigrants in the European Union. Retrieved March 24, 2019, from https://ec.europa.eu/commfrontoffice/publicopinion/index.cfm/ResultDoc/.../82537

EU Court Rules Hungary Broke Asylum Law by Detaining Migrants. (2020, December 17). Retrieved March 30, 2021, from https://www.rferl.org/a/hungary-eu-court-migrants-asylum-lawbroken/31005770.html

European Union Terrorism Situation and Trend Report 2020. (2020). Europol, 1-97.

EU to sue Poland, Hungary and Czechs for refusing refugee quotas. (2017, December 07). Retrieved March 24, 2019, from http://www.bbc.com/news/world-europe-42270239 
Facilitation of Illegal Immigration. (n.d.). Retrieved December 16, 2020, from https://www.europol.europa.eu/crime-areas-and-trends/crime-areas/facilitation-of-illegalimmigration?ct $\% 5$ Barticle $\% 5 \mathrm{D}=$ article

Full speech of V. Orbán: Will Europe belong to Europeans? (2017, July 24). Retrieved March 30, 2021, from https://visegradpost.com/en/2017/07/24/full-speech-of-v-orban-will-europe-belong-toeuropeans/

Hungary: Government Extends the "State of Crisis due to Mass Migration". (2019, September 13). Retrieved March 30, 2021, from https://www.ecre.org/hungary-government-extends-the-state-ofcrisis-due-to-mass-migration/

Hungary passes 'Stop Soros' law banning help for migrants. (2018, June 20). Retrieved March 30, 2021, from https://www.bbc.com/news/world-europe-44546030

Hungary's National Security Strategy 2012. (2021). Ministry of Foreign Affairs of Hungary, 1-23.

Hungary-Tunisia Defence and Police Cooperation. (2019, January 24). Retrieved December 16, 2020, from https://hungarytoday.hu/hungary-tunisia-defence-and-police-cooperation/

Kaminski, M. (2015, December 02). 'All the terrorists are migrants'. Retrieved March 30, 2021, from https://www.politico.eu/article/viktor-orban-interview-terrorists-migrants-eu-russia-putinborders-schengen/

Koncz, Tamás. (n.d.). Tudta? Idén plusz 90 milliárd megy el terrorelhárításra. Retrieved December 16, 2020, from https://magyarnemzet.hu/archivum/belfold-archivum/tudta-iden-plusz-90-milliardmegy-el-terrorelharitasra-3871059/

Mno.hu. (n.d.). Budapesten is terveztek terrorakciót. Retrieved December 16, 2020, from https://www.vg.hu/kozelet/budapesten-is-terveztek-terrorakciot-444186/

Prime Minister Viktor Orbán's speech at the Hungarian Chamber of Commerce and Industry's ceremony to mark the start of the 2017 business year. (2017, February 28). Retrieved December 16, 2020, from http://www.miniszterelnok.hu/prime-minister-viktor-orbans-speech-at-the-hungarianchamber-of-commerce-and-industrys-ceremony-to-mark-the-start-of-the-2017-business-year/

Simonovits, B., \& Bernát, A. (2016). The Social Aspects of the 2015 Migration Crisis in Hungary. TÁRKI Social Research Institute, 1-155. Retrieved March 24, 2019, from http://old.tarki.hu/hu/news/2016/kitekint/20160330_refugees.pdf

Wæver, O. (1996). European Security Identities. Journal of Common Market Studies, Vol. 34(No. 1), 103-132.

Wæver, O. (2002). Securitization and Desecuritization. Columbia International Affairs Online.

Orbán Viktor a Kossuth Rádió "180 perc" címü müsorában (2015.11.20.). (2015, November 20). Retrieved March 30, 2021, from https://miniszterelnok.hu/orban-viktor-a-kossuth-radio-180-perccimu-musoraban-20151120/ 
Orbán Viktor a Kossuth Rádió "180 perc" címü müsorában. (2016, January 22). Retrieved March 30, 2021, from https://miniszterelnok.hu/orban-viktor-a-kossuth-radio-180-perc-cimu-musoraban20160122/

Orbán Viktor beszéde a Fidesz - Magyar Polgári Szövetség XXVI. kongresszusán. (2015, December 13). Retrieved March 30, 2021, from https://miniszterelnok.hu/orban-viktor-beszede-a-fidesz-magyarpolgari-szovetseg-xxvi-kongresszusan/

Orbán Viktor beszéde a határvadászok eskütételén. (2017, January 12). Retrieved March 30, 2021, from https://miniszterelnok.hu/orban-viktor-beszede-a-hatarvadaszok-eskutetelen/

Orbán Viktor beszéde a II. Budapesti Demográfiai Fórumon. (2017, May 25). Retrieved March 30, 2021, from https://miniszterelnok.hu/orban-viktor-beszede-a-ii-budapesti-demografiai-forumon/

Orbán Viktor beszéde a MAGYAR diaszpóra Tanács V. Ülésén. (2015, December 2). Retrieved March 30, 2021, from https://miniszterelnok.hu/orban-viktor-beszede-a-magyar-diaszpora-tanacs-vulesen/

Orbán Viktor beszéde a MAZSIHISZ székházában. (2017, July 19). Retrieved March 30, 2021, from https://miniszterelnok.hu/orban-viktor-beszede-a-mazsihisz-szekhazaban/

Orbán Viktor beszéde a nemzeti konzultáció záróeseményén. (2017, June 27). Retrieved March 30, 2021, from https://miniszterelnok.hu/orban-viktor-beszede-a-nemzeti-konzultacio-zaroesemenyen/

Orbán Viktor előadása a XXVII. Bálványosi Nyári SZABADEGYETEM és Diáktáborban. (2016, July 23). Retrieved March 30, 2021, from https://miniszterelnok.hu/orban-viktor-eloadasa-a-xxviibalvanyosi-nyari-szabadegyetem-es-diaktaborban/

Orbán Viktor előadása az "Európa jövője" című V4-konferencián. (2018, January 26). Retrieved March 30, 2021, from https://miniszterelnok.hu/orban-viktor-eloadasa-az-europa-jovoje-cimu-v4konferencian/

Orbán Viktor felszólalása a Kereszténydemokrata Internacionálé vallásközi párbeszédről szóló nemzetközi konferenciáján. (2018, February 16). Retrieved March 30, 2021, from https://miniszterelnok.hu/orban-viktor-felszolalasa-a-keresztenydemokrata-internacionalevallaskozi-parbeszedrol-szolo-nemzetkozi-konferenciajan/

Orbán Viktor felszólalása az Európai Néppárt kongresszusán. (2017, March 30). Retrieved March 30, 2021, from https://miniszterelnok.hu/orban-viktor-felszolalasa-az-europai-neppart-kongresszusan/

Orbán Viktor interjúja a Bild címü német napilapnak. (2016, February 25). Retrieved March 30, 2021, from https://miniszterelnok.hu/orban-viktor-interjuja-a-bild-cimu-nemet-napilapnak/

Orbán Viktor interjúja a Kossuth Rádió "180 Perc" című müsorában. (2016, August 26). Retrieved March 30, 2021, from https://miniszterelnok.hu/orban-viktor-interjuja-a-kossuth-radio-180-perc-cimumusoraban-2016augusztus26/

Orbán Viktor interjúja a Kossuth Rádió "Jó reggelt, Magyarország!" című müsorában. (2018, November 9). Retrieved March 30, 2021, from https://miniszterelnok.hu/orban-viktor-interjuja-a-kossuthradio-jo-reggelt-magyarorszag-cimu-musoraban-3/ 
Orbán Viktor interjúja a Magyar Rádió „Vasárnapi Újság” címü müsorában. (2016, September 25). Retrieved March 30, 2021, from https://miniszterelnok.hu/3736-2/

Orbán Viktor interjúja a Vasárnapi Újságnak. (2018, March 25). Retrieved March 30, 2021, from https://miniszterelnok.hu/orban-viktor-interjuja-a-vasarnapi-ujsagnak/

Orbán Viktor magyar és Peter Pellegrini szlovák miniszterelnök közös televíziós interjúja a TA3 szlovák kereskedelmi csatornának. (2018, June 24). Retrieved March 30, 2021, from

https://miniszterelnok.hu/orban-viktor-magyar-es-peter-pellegrini-szlovak-miniszterelnok-kozostelevizios-interjuja-a-ta3-szlovak-kereskedelmi-csatornanak/

Orbán Viktor miniszterelnök televíziós interjúja a cseh TV Barrandov "Párbaj” (Duel) címü müsorában. (2018, November 30). Retrieved March 30, 2021, from https://miniszterelnok.hu/orban-viktorminiszterelnok-televizios-interjuja-a-cseh-tv-barrandov-parbaj-duel-cimu-musoraban/

Orbán Viktor napirend előtti felszólalása. (2017, September 18). Retrieved March 30, 2021, from https://miniszterelnok.hu/orban-viktor-napirend-elotti-felszolalasa-5/

Orbán Viktor nyilatkozata a Magyar Televíziónak. (2017, March 25). Retrieved March 30, 2021, from https://miniszterelnok.hu/orban-viktor-nyilatkozata-a-magyar-televizionak-2/

Orbán Viktor nyilatkozata a New York-i terrortámadások 15. évfordulóján. (2016, September 11). Retrieved March 30, 2021, from https://miniszterelnok.hu/orban-viktor-nyilatkozata-a-new-yorki-terrortamadasok-15-evfordulojan/

Orbán Viktor sajtónyilatkozata a NATO-csúcsot követően. (2019, December 4). Retrieved March 30, 2021, from https://miniszterelnok.hu/orban-viktor-sajtonyilatkozata-a-nato-csucsot-kovetoen/

Orbán Viktor sajtónyilatkozata a Visegrádi Négyek és Izrael Állam miniszterelnökének találkozóját követően. (2017, July 19). Retrieved March 30, 2021, from https://miniszterelnok.hu/orbanviktor-sajtonyilatkozata-a-visegradi-negyek-es-izrael-allam-miniszterelnokenek-talalkozojatkovetoen/

Orbán Viktor sajtónyilatkozata Benjámin Netanjahuval, Izrael miniszterelnökével történt tárgyalás elött. (2018, July 19). Retrieved March 30, 2021, from https://miniszterelnok.hu/orban-viktorsajtonyilatkozata-benjamin-netanjahuval-izrael-miniszterelnokevel-tortent-targyalas-elott/

Orbán Viktor évértékelő beszéde. (2016, February 28). Retrieved March 30, 2021, from https://miniszterelnok.hu/orban-viktor-evertekelo-beszede/

Orbán Viktor évértékelő beszéde. (2019, February 10). Retrieved March 30, 2021, from https://miniszterelnok.hu/orban-viktor-evertekelo-beszede-3/

PM Viktor ORBÁN: "Europe is under Attack" Hungarian Parliament Speech 2015. 11. 16 [Video file]. (2015, November 16). Retrieved March 30, 2021, from https://www.youtube.com/watch?v=qzjXj7FZ4o8

Speech of Viktor Orbán at the EPP congress. (n.d.). Retrieved March 30, 2021, from https://20152019.kormany.hu/en/the-prime-minister/the-prime-minister-s-speeches/speech-of-viktor-orbanat-the-epp-congress 20151024 
State of Play: Measures to Address the Refugee Crisis. (2016, January 29). Retrieved March 30, 2021, from https://ec.europa.eu/commission/presscorner/detail/en/IP_15_6134

Strengthening cooperation on migration and refugee movements in the perspective of the new development agenda. (2015, September 30). Retrieved March 30, 2021, from https://www.un.org/en/development/desa/population/migration/events/ga/2015/docs/statements/H UNGARY.pdf

Viktor orbán's press statement after his talks with Prime Minister of Bulgaria Boyko Borissov. (2016, January 29). Retrieved March 30, 2021, from http://www.miniszterelnok.hu/viktor-orbans-pressstatement-after-his-talks-with-prime-minister-of-bulgaria-boyko-borissov/

Viktor Orbán's speech at the 14th Kötcse civil picnic. (2015, September 17). Retrieved March 30, 2021, from http://2010-

2015.miniszterelnok.hu/in_english_article/viktor_orban_s_speech_at_the_14th_kotcse_civil_picn ic

Viktor orbán's speech at the opening of the World Science Forum. (n.d.). Retrieved March 30, 2021, from http://2010-

2015.miniszterelnok.hu/in_english_article/viktor_orban_s_speech_at_the_opening_of_the_world _science_forum

Working together to protect U.S. organizations overseas. (2019, March 28). Retrieved April 02, 2021, from https://www.osac.gov/Country/Hungary/Content/Detail/Report/b4b9a3ab-2fa2-415e-91dd15f4aebdaaca 